\title{
Thoracic Surgeon
}

National Cancer Institute

\section{Source}

National Cancer Institute. Thoracic Surgeon. NCI Thesaurus. Code C17836.

A surgeon who specializes in treatment of diseases and disorders of the chest, heart and lungs. 